\title{
The Relationship Between Dipeptidyl Peptidase-4 Inhibitor Usage and Asymptomatic Amylase Lipase Increment in Type 2 Diabetes Mellitus Patients
}

\author{
Tip 2 Diabetes Mellitus Tanılı Hastalarda Dipeptidil Peptidaz-4 İnhibitör \\ Kullanımı ile Asemptomatik Amilaz Lipaz Artışı Arasındaki ilişki
}

\author{
(D) Zeynel Abidin SAYINER* (D) Gamze INAN DEMIROĞLU2, (D) Ersin AKARSU1', (D) Mustafa ARAZ1 \\ ${ }^{1}$ Gaziantep University, School of Medicine, Department of Endocrinology and Metabolism, Gaziantep, Turkey \\ 2Gaziantep University, School of Medicine, Department of Internal Medicine, Gaziantep, Turkey
}

\begin{abstract}
Objectives: In different studies, it has been shown that the use of dipeptidyl peptidase-4 (DPP-4) inhibitors (DPP-4 inh) does not increase the risk of pancreatitis or pancreatic cancer. Although the number of studies involving clinical pancreatitis clinics is sufficient, the number of studies involving clinical non-pancreatitis hyperamylasemia is rare. The aim of the study was to investigate the relationship between DPP-4 inh usage and amylase and lipase increment without clinical pancreatitis symptoms.

Materials and Methods: Eighty-seven patients who met the inclusion criteria were enrolled. The patients were divided into 3 groups according to their use of saxagliptin, sitagliptin, or vildagliptin. All patients included in the study were receiving metformin at a dose of $2 \mathrm{~g} / \mathrm{day}$. Fasting blood glucose, postprandial blood glucose, $\mathrm{HbA1C}$, serum creatinine, ALT, amylase, and lipase results were recorded at the beginning of treatment and at the end of 3 months.

Results: There was an increase in all groups in terms of amylase and lipase values but there was no significant difference between the groups in terms of increase ( $p>0.05$ ) There was no statistically significant increase in the saxagliptin and vildagliptin groups ( $p>0.05)$ when the baseline and 3 -month values of lipase and amylase increase were examined. However, there was a statistically significant increase in amylase and lipase in the sitagliptin group ( $p<0.05)$.

Conclusion: The use of DPP-4 inh can increase amylase and lipase levels without clinical findings of acute pancreatitis in the patient. DPP-4 inh should be used with caution in patients at risk for pancreatitis and pancreatic cancer. Patients using DPP-4 inh, especially sitagliptin, should be evaluated carefully for pancreatitis risk factors.
\end{abstract}

Key words: Oral antidiabetics, dipeptidyl peptidase-4 inhibitors, amylase, lipase

Öz

Amaç: Farklı çalışmalarda, dipeptidil peptidaz-4 (DPP-4) inhibitörünün (DPP-4 inh) kullanımının pankreatit ve pankreas kanseri riskini artırdığı gösterilmiştir. Her ne kadar pankreatit klinikleri ile yapılan çalışmaların sayısı yeterli olsa da, klinik olarak pankreatit olmayan hiperaldemi ile yapılan çalışmaların sayısı azdır. Çalışmanın amacı, DPP-4 inh kullanımı ile pankreatit semptomları olmadan amilaz ve lipaz artışı arasındaki ilişkiyi araștırmaktır.

Gereç ve Yöntemler: Çalışmaya dahil edilme kriterlerlerine uyan 87 hasta alındı. Hastalar saksagliptin, sitagliptin ve vildagliptin kullanımlarına göre 3 gruba ayrıldı. Çalışmaya dahil edilen tüm hastalar 2 gram/gün dozda metformin aldı. Açlık kan şekeri, post prandial kan şekeri, HbA1c, serum kreatinin, ALT, amilaz, lipaz sonuçları tedavi başlangıcında ve 3. ayın sonunda kaydedildi.

Bulgular: Amilaz ve lipaz değerleri açısından tüm gruplarda artış vardı ve gruplar arasında artma açısından anlamlı fark yoktu (p>0,05). Saksagliptin ve vildagliptin grubunda istatistiksel olarak anlamlı bir artış yoktu ( $>0,05)$ Lipaz ve amilaz artışının başlangıç ve 3. ay değerleri incelendiğinde sadece sitagliptin grubunda istatistiksel olarak anlamlı bir amilaz ve lipaz artışı vardı ( $p<0.05$ ).

Sonuç: DPP-4 inh kullanımı, akut pankreatitin klinik bulguları olmaksızın amilaz ve lipaz seviyelerini arttırabilir. DPP-4 inh pankreatit ve pankreatik kanser riski olan hastalarda dikkatli kullanılmalıdır. DPP-4 inh, özellikle sitagliptin kullanan hastalar pankreatit risk faktörleri açısından dikkatle değerlendirilmelidir.

Anahtar kelimeler: Oral antidiyabetikler, dipeptidil peptidaz-4 inhibitörleri, amilaz, lipaz

*Correspondence: E-mail: zeynelasayiner@hotmail.com, Phone: +90 3423606060 ORCID-ID: orcid.org/0000-0001-5105-0292

Received: 21.08.2018, Accepted: 25.10.2018

๑Turk J Pharm Sci, Published by Galenos Publishing House. 


\section{INTRODUCTION}

Dipeptidyl peptidase 4 (DPP-4), an aminopeptidase that was isolated from the rat liver in 1960, is excreted in the pancreas, brain, lungs, kidneys, intestines, adrenal glands, and lymph nodes., ${ }^{1,2}$ Moreover, this enzyme causes glucagon-like peptide-1 (GLP-1) to break down in less than 2 min and gastric inhibitory polypeptide in less than 5 to $7 \mathrm{~min}^{3.4}$ Dipeptidyl peptidase-4 inhibitors (DPP-4 inh) are oral antidiabetic agents that increase circulating GLP-1 levels. Thus, they help to inhibit the rapid inactivation of GLP-1 and regulate blood sugar. In other words, they control blood glucose by stimulating insulin secretion in glucose-dependent pathways. ${ }^{5}$ Although DPP-4 contains a wide range of substrates including chemokines, hormones, and neuropeptides, DPP-4 inh usually do not negatively affect type 2 diabetes (T2DM) patients. Several studies have evaluated the safety of DPP-4 inh in elderly patients as well as patients with renal insufficiency, liver disease, and/or heart failure. While most observational studies have demonstrated the safety of these inhibitors, they have nevertheless been associated with a slightly increased incidence of acute pancreatitis during placebo-controlled trials. In addition, the possible side effects of long-term DPP-4 inh use remain unclear. ${ }^{6}$ Those side effects observed during the preclinical and clinical trials of sitagliptin and vildagliptin treatments are inconsistent with the increased risk of pancreatitis in T2DM patients, but the association between DPP-4 inh and pancreatic cancer, pancreatitis, and pancreatic enzyme elevation has been proven. ${ }^{7}$ The Food and Drug Administration (FDA) has also reported that patients using sitagliptin and exenatide should be cautious in terms of developing pancreatic cancer. ${ }^{7}$ On the other hand, various studies have demonstrated that the use of DPP-4 inh does not increase the risk of pancreatitis or pancreatic cancer. ${ }^{8}$ Finally, although the number of studies involving pancreatic cancer patients is sufficient, those concerning patients with clinical non-pancreatic hyperamylasemia are rare. The present study assessed changes in the amylase and lipase values of various patients who had been using DPP-4 inh but did not exhibit acute pancreatitis symptoms.

\section{MATERIALS AND METHODS}

The participants were diabetic patients who had been referred to the endocrinology and metabolism clinic of Gaziantep Şahinbey research and application hospital. Prior to the study, approval (approval no. 17/10/2016/268) was obtained from the Gaziantep University Committee. The study was prospective in nature, with patients being evaluated twice over a 3-month period (i.e. at 0 and 3 months). In addition, it was descriptive in nature and assessed the relationship among variables. All patients involved in this study met the following inclusion criteria developed by the American Diabetes Association :

\section{Patients with T2DM}

2. Patients who were not using antidiabetic drugs other than metformin and previously had not used sitagliptin, saxagliptin, or vildagliptin

3. Patients with $\mathrm{HbA} 1 \mathrm{C}$ level lower than 10
4. Patients without cholelithiasis,

5. Patients without chronic alcohol consumption,

6. Patients with triglyceride levels lower than $150 \mathrm{mg} / \mathrm{dL}$,

7. Patients in whom blood sugar regulation could not be achieved with metformin or any form of sitagliptin, saxagliptin, or vildagliptin treatment,

8. Patients without pancreatitis or pancreatitis history,

9. Patients with no history of renal or hepatic disease,

10. Patients without acute malignancy or malignancy history

11. Patients who were not pregnant,

The 87 patients who met the above criteria were divided into 3 groups according to their use of saxagliptin, sitagliptin, or vildagliptin. All had been taking metformin at a dosage of $2 \mathrm{~g} /$ day at the start of the study. Patients using saxagliptin had been taking $1 \mathrm{mg}$ of $5 \mathrm{mg}$ daily, patients using sitagliptin had been taking $100 \mathrm{mg}$ daily, and patients using vildagliptin had been taking $50 \mathrm{mg}$ daily (morning and evening). Prior to and following the 3-month treatment, patients' fasting blood glucose, postprandial blood glucose, hemoglobin A1c ( $\mathrm{HbA1C}$ ), serum creatinine, alanine transaminase (ALT), amylase, and lipase levels were recorded.

\section{Statistical analysis}

A minimum of 80 patients were required for the present study based on the results of power analysis conducted for sample selection. The normal distribution fitness of numerical data was tested using the Shapiro-Wilk test, while the Kruskal-Wallis test was used to compare normal nondispersive variables. The relationship among normally undistracted dependent variables was tested via the Wilcoxon test, and the relationship among categorical variables was tested using the chi-square test. SPSS 22.0 was employed for results analysis and a p-value $<0.05$ was considered significant.

\section{RESULTS}

There was no statistically significant difference among the groups in terms of age or sex ( $p>0.05)$. The demographic characteristics of each group of participants are shown in Table 1.

At the beginning of the study, no significant difference in baseline fasting glucose level or postprandial blood glucose, $\mathrm{HbA} 1 \mathrm{C}$, serum creatinine, ALT, amylase, or lipase was observed ( $p>0.05$ ) (Table 2). A statistically significant decrease in all groups ( $p>0.05$ ) was found in fasting blood glucose, postprandial blood glucose, and $\mathrm{HbA1C}$ values after the 3-month treatment. Moreover, amylase and lipase values increased in all groups,

Table 1. Demographic characteristics of the groups

\begin{tabular}{lllll} 
& $\begin{array}{l}\text { Saxagliptin } \\
\mathrm{n}=27\end{array}$ & $\begin{array}{l}\text { Sitagliptin } \\
\mathrm{n}=30\end{array}$ & $\begin{array}{l}\text { Vildagliptin } \\
\mathrm{n}=30\end{array}$ & $\mathrm{p}$ \\
\hline $\begin{array}{l}\text { Sex } \\
\text { (female/male) }\end{array}$ & $21 / 6$ & $7 / 23$ & $12 / 18$ & 0.241 \\
\hline Age (year) & $54.26 \pm 7.906$ & $56.33 \pm 6.572$ & $54.00 \pm 10.316$ & 0.577
\end{tabular}


but there was no significant difference in these values when comparing the groups ( $p>0.05$ ) (Table 3 ). By the end of the study, there was a statistically significant decrease in fasting blood glucose and $\mathrm{HbA1C}$ in all groups ( $p<0.05$ ). However, in comparing the groups, the decline rates did not significantly differ. There was no statistically significant increase in lipase or amylase levels within the saxagliptin and vildagliptin groups ( $p>0.05$ ) after the 3-month treatment. However, there was a statistically significant increase in amylase and lipase levels within the sitagliptin group ( $p<0.05)$. There was no statistically

Table 2. Comparison of laboratory parameters of the groups at the beginning of treatment

\begin{tabular}{|c|c|c|c|c|c|}
\hline & & $\mathrm{N}$ & Mean & $\begin{array}{l}\text { Std. } \\
\text { deviation }\end{array}$ & $\mathrm{p}$ \\
\hline \multirow{4}{*}{$\begin{array}{l}\text { Fasting } \\
\text { glucose } \\
\text { (mg/dL) }\end{array}$} & Saxagliptin & 27 & 204.41 & 69.841 & \multirow{4}{*}{0.704} \\
\hline & Sitagliptin & 30 & 190.67 & 66.093 & \\
\hline & Vildagliptin & 30 & 215.73 & 91.480 & \\
\hline & Total & 87 & 203.57 & 76.679 & \\
\hline \multirow{4}{*}{$\begin{array}{l}\text { Postprandial } \\
\text { glucose (mg/ } \\
\text { dL) }\end{array}$} & Saxagliptin & 27 & 344.30 & 112.314 & \multirow{4}{*}{0.621} \\
\hline & Sitagliptin & 30 & 275.97 & 114.564 & \\
\hline & Vildagliptin & 30 & 327.90 & 126.681 & \\
\hline & Total & 87 & 315.08 & 120.458 & \\
\hline \multirow{4}{*}{$\mathrm{HbA} 1 \mathrm{C}(\%)$} & Saxagliptin & 27 & 9.41 & 2.005 & \multirow{4}{*}{0.700} \\
\hline & Sitagliptin & 30 & 8.97 & 1.650 & \\
\hline & Vildagliptin & 30 & 9.27 & 1.874 & \\
\hline & Total & 87 & 9.21 & 1.831 & \\
\hline \multirow{4}{*}{$\begin{array}{l}\text { Creatinine } \\
(\mathrm{mg} / \mathrm{dL})\end{array}$} & Saxagliptin & 27 & 0.93 & 0.267 & \multirow{4}{*}{0.885} \\
\hline & Sitagliptin & 30 & 0.90 & 0.305 & \\
\hline & Vildagliptin & 30 & 0.93 & 0.254 & \\
\hline & Total & 87 & 0.92 & 0.274 & \\
\hline \multirow{4}{*}{ ALT (U/L) } & Saxagliptin & 27 & 23.07 & 10.954 & \multirow{4}{*}{0.905} \\
\hline & Sitagliptin & 30 & 24.57 & 10.448 & \\
\hline & Vildagliptin & 30 & 22.63 & 9.368 & \\
\hline & Total & 87 & 23.44 & 10.168 & \\
\hline \multirow{4}{*}{$\begin{array}{l}\text { Amylase } \\
(\mathrm{U} / \mathrm{L})\end{array}$} & Saxagliptin & 27 & 60.74 & 21.506 & \multirow{4}{*}{0.792} \\
\hline & Sitagliptin & 30 & 56.77 & 22.660 & \\
\hline & Vildagliptin & 30 & 56.03 & 21.714 & \\
\hline & Total & 87 & 57.75 & 21.821 & \\
\hline \multirow{4}{*}{ Lipase (U/L) } & Saxagliptin & 27 & 19.65 & 12.776 & \multirow{4}{*}{0.394} \\
\hline & Sitagliptin & 30 & 25.32 & 17.035 & \\
\hline & Vildagliptin & 30 & 21.82 & 14.274 & \\
\hline & Total & 87 & 22.35 & 15.297 & \\
\hline
\end{tabular}

HbA1C: Hemoglobin A1c, ALT: Alanine transaminase, Std: Standard significant increase in ALT levels within the sitagliptin or vildagliptin groups ( $p>0.05$ ), yet there was a statistically significant increase in ALT level within the saxagliptin group (p<0.05) (Table 4).

\section{DISCUSSION}

Sitagliptin, which has been used since 2006, is the longest of the DPP-4 inh in use; thus, more information is available regarding its use compared to other DPP-4 inh. According to the FDA's reported side effect database, patients using sitagliptin or exenatide are more prone to develop pancreatic cancer than

\section{Table 3. Laboratory parameters of the groups by the end of} treatment

\begin{tabular}{|c|c|c|c|c|c|}
\hline & & $\mathrm{N}$ & Mean & $\begin{array}{l}\text { Std. } \\
\text { deviation }\end{array}$ & $\mathrm{p}$ \\
\hline \multirow{4}{*}{$\begin{array}{l}\text { Fasting glucose } \\
(\mathrm{mg} / \mathrm{dL})\end{array}$} & Saxagliptin & 27 & 155.48 & 49.431 & \multirow{4}{*}{0.171} \\
\hline & Sitagliptin & 30 & 162.67 & 52.948 & \\
\hline & Vildagliptin & 30 & 182.37 & 61.222 & \\
\hline & Total & 87 & 167.23 & 55.484 & \\
\hline \multirow{4}{*}{$\begin{array}{l}\text { Postprandial } \\
\text { glucose (mg/dL) }\end{array}$} & Saxagliptin & 27 & 277.67 & 99.458 & \multirow{4}{*}{0.402} \\
\hline & Sitagliptin & 30 & 251.73 & 108.690 & \\
\hline & Vildagliptin & 30 & 271.97 & 109.553 & \\
\hline & Total & 87 & 266.76 & 105.579 & \\
\hline \multirow{4}{*}{ HbA1C (\%) } & Saxagliptin & 27 & 8.11 & 1.450 & \multirow{4}{*}{0.154} \\
\hline & Sitagliptin & 30 & 7.80 & 1.375 & \\
\hline & Vildagliptin & 30 & 8.57 & 1.569 & \\
\hline & Total & 87 & 8.16 & 1.485 & \\
\hline \multirow{4}{*}{$\begin{array}{l}\text { Creatinine (mg/ } \\
\mathrm{dL})\end{array}$} & Saxagliptin & 27 & 0.96 & 0.192 & \multirow{4}{*}{0.800} \\
\hline & Sitagliptin & 30 & 0.93 & 0.254 & \\
\hline & Vildagliptin & 30 & 0.97 & 0.183 & \\
\hline & Total & 87 & 0.95 & 0.211 & \\
\hline \multirow{4}{*}{ ALT (U/L) } & Saxagliptin & 27 & 26.00 & 10.269 & \multirow{4}{*}{0.937} \\
\hline & Sitagliptin & 30 & 25.13 & 11.697 & \\
\hline & Vildagliptin & 30 & 25.47 & 13.364 & \\
\hline & Total & 87 & 25.52 & 11.763 & \\
\hline \multirow{4}{*}{ Amylase (U/L) } & Saxagliptin & 27 & 63.33 & 22.675 & \multirow{4}{*}{0.646} \\
\hline & Sitagliptin & 30 & 67.13 & 20.416 & \\
\hline & Vildagliptin & 30 & 62.00 & 27.188 & \\
\hline & Total & 87 & 64.18 & 23.456 & \\
\hline \multirow{4}{*}{ Lipase (U/L) } & Saxagliptin & 27 & 35.41 & 18.158 & \multirow{4}{*}{0.249} \\
\hline & Sitagliptin & 30 & 42.23 & 20.992 & \\
\hline & Vildagliptin & 30 & 34.10 & 18.713 & \\
\hline & Total & 87 & 37.31 & 19.482 & \\
\hline
\end{tabular}

HbA1C: Hemoglobin A1c, ALT: Alanine transaminase, Std: Standard 
Table 4. Comparison of laboratory parameters at the beginning and end of treatment

\begin{tabular}{|c|c|c|c|c|}
\hline \multicolumn{2}{|l|}{ Mean \pm Std } & \multirow{2}{*}{$\begin{array}{l}\text { Beginning } \\
\text { Mean } \pm \text { Std }\end{array}$} & \multicolumn{2}{|l|}{3 Months } \\
\hline \multirow{4}{*}{$\begin{array}{l}\text { Fasting } \\
\text { glucose }\end{array}$} & & & & \\
\hline & Saxagliptin & $204.4 \pm 69.9$ & $155.5 \pm 49.4$ & 0.001 \\
\hline & Sitagliptin & $190.7 \pm 66.1$ & $162.7 \pm 52.9$ & 0.018 \\
\hline & Vildagliptin & $215.7 \pm 91.5$ & $182.4 \pm 61.2$ & 0.005 \\
\hline \multirow{3}{*}{$\begin{array}{l}\text { Postprandial } \\
\text { glucose }\end{array}$} & Saxagliptin & $344.3 \pm 112.3$ & $277.7 \pm 99.5$ & 0.001 \\
\hline & Sitagliptin & $275.9 \pm 114.6$ & $251.7 \pm 108.7$ & 0.098 \\
\hline & Vildagliptin & $327.9 \pm 126.7$ & $271.9 \pm 109.6$ & 0.001 \\
\hline \multirow[t]{3}{*}{$\mathrm{HbA1C}$} & Saxagliptin & $9.4 \pm 2.0$ & $8.1 \pm 1.5$ & 0.001 \\
\hline & Sitagliptin & $8.9 \pm 1.6$ & $7.8 \pm 1.4$ & 0.001 \\
\hline & Vildagliptin & $9.3 \pm 1.9$ & $8.6 \pm 1.6$ & 0.007 \\
\hline \multirow[t]{3}{*}{ Amylase } & Saxagliptin & $60.7 \pm 21.5$ & $63.3 \pm 22.7$ & 0.400 \\
\hline & Sitagliptin & $56.8 \pm 22.7$ & $67.1 \pm 20.4$ & 0.001 \\
\hline & Vildagliptin & $56.0 \pm 21.7$ & $62.0 \pm 27.2$ & 0.174 \\
\hline \multirow[t]{3}{*}{ Lipase } & Saxagliptin & $19.7 \pm 12.8$ & $35.4 \pm 18.2$ & 0.360 \\
\hline & Sitagliptin & $25.3 \pm 17.0$ & $42.2 \pm 20.9$ & 0.001 \\
\hline & Vildagliptin & $21.8 \pm 14.3$ & $34.1 \pm 18.7$ & 0.090 \\
\hline \multirow[t]{3}{*}{ Creatinine } & Saxagliptin & $0.9 \pm 0.3$ & $0.9 \pm 0.2$ & 0.564 \\
\hline & Sitagliptin & $0.9 \pm 0.3$ & $0.9 \pm 0.3$ & 0.564 \\
\hline & Vildagliptin & $0.9 \pm 0.3$ & $0.9 \pm 0.2$ & 0.564 \\
\hline \multirow[t]{3}{*}{ ALT } & Saxagliptin & $23.1 \pm 10.9$ & $26.0 \pm 10.3$ & 0.037 \\
\hline & Sitagliptin & $24.6 \pm 10.5$ & $25.1 \pm 11.7$ & 0.789 \\
\hline & Vildagliptin & $22.6 \pm 9.4$ & $25.5 \pm 13.4$ & 0.096 \\
\hline
\end{tabular}

HbA1C: Hemoglobin A1c, ALT: Alanine transaminase, Std: Standard

those using other drugs. ${ }^{9}$ Moreover, it has been claimed that chronic subclinical pancreatitis due to GLP-1 therapy may cause an increase in the incidence of pancreatic cancer. ${ }^{10}$

The above assertions have been supported by studies demonstrating that long-term exendin-4-mediated GLP-1R activation proliferates the development of pancreatic duct glands and the formation of dysplastic lesions (low grade intraepithelial neoplasia-mPANIN) in rats as well as chronic pancreatitis in the KrasG12D mouse model. ${ }^{11}$ These studies have observed GLP-1-induced changes in pancreatic duct glands as well as genetic predisposition to cellular dysplasia. Therefore, it has been assumed that the absence of both a clear pancreatitis pattern and tumors in lean and nondiabetic animals receiving extendin- 4 therapy owes itself to two facts. First, these animals are not genetically predisposed to dysplasia, and, second, the methodological analysis used to detect changes in the pancreas is not suitable for these animals. ${ }^{12,13}$ For this reason, it has been suggested that in the case of chronic pancreatitis the pancreatic duct glands can easily transform into PanIN-like lesions. ${ }^{14,15}$ Although exendin- 4 administration leads to the development of
$\mathrm{mPan} I \mathrm{~N}$, it has not been scientifically proven that drug treatment in subjects does not lead to pancreatic cancer in genetically modified mice since this treatment has not been long enough in terms of duration. ${ }^{16}$ At the same time, Butler et al. ${ }^{17}$ have reported that patients receiving incretin therapy experience exocrine pancreatic dysplasia and endocrine pancreatic cell proliferation. On the other hand, the limited number of patients and treatment involved in Butler et al..$^{7}$ study as well as the lack of statistical data might have caused this link between therapy and cancer..$^{18,19}$

In previous studies, cases of pancreatitis associated with the use of DPP- 4 inh have been presented as case reports. ${ }^{20}$ However, retrospective studies and meta-analyses have reported that these drugs are not statistically significant in terms of causing pancreatitis compared to other antidiabetic drugs. ${ }^{21}$ In the current study, although there was an increase in amylase and lipase in patients, no significant difference was seen in any patient possessing the characteristics of acute pancreatitis. In their study of acute pancreatitis among T2DM patients in Taiwan, Hsin-Chuo et al. ${ }^{22}$ determined the use of DPP-4 inh to be a risk factor for the presence of cholelithiasis and uncontrolled diabetes mellitus. On the other hand, in another retrospective cohort study conducted by Daisuke Yabe et al. ${ }^{23}$ in Japan among 93,280 antidiabetic patients who had been screened for acute pancreatitis and used 27,962 DPP-4 inh, no significant difference was observed in terms of acute pancreatitis development.

Studies have also emerged regarding the use of DPP-4 inh for elevating amylase and lipase from pancreatic exocrine enzymes. In a 3-month prospective study observing the amylase and lipase levels of 36 patients, 24 of whom were using DPP4 inh and 12 of whom were taking other antidiabetic drugs, Tokuyama et al..$^{24}$ observed an elevation in amylase and lipase levels among 11 out of 24 patients receiving DPP-4 inh that was regarded as statistically significant. In the present study, a baseline increase in amylase and lipase was observed in all groups. However, there was no statistically significant increase in the saxagliptin or vildagliptin groups ( $p>0.05)$, whereas a statistically significant increase was observed in the sitagliptin group.

The greater number of studies concerning sitagliptin in DPP4-associated pancreatitis cases presented as case reports may be related to the longer treatment duration of sitagliptin in comparison to other DPP-4 inh. Still, some theoretical information (especially that derived from animal experiments) is available that indicates the cause of the increase in pancreatic enzymes with the use of DPP-4. Studies examining the relationship between sitagliptin and oxidative stress as well as inflammation have indicated that sitagliptin increases the levels of tumor necrosis factor-alpha in serum inflammatory stores. Moreover, it has been found to decrease oxidative stress in serum by decreasing serum IL-1 $\beta$ levels and reducing serum total malondialdehyde levels but not total antioxidant levels. Another study examining the effects of sitagliptin on oxidative 
stress has reported that the total oxidant levels in diabetic rat pancreatic tissues did not change but oxidative stress increased due to decreased total antioxidant levels. This increased oxidative stress, which is likely to occur in the pancreas tissue, causes some inflammation in the exocrine pancreas. However, it is unclear whether this level can cause pancreatitis. Despite the inflammation and dysplastic changes in animal experiments examining the exocrine pancreas, the use of DPP-4 inh has been shown to increase function and mass in pancreatic beta cells. ${ }^{25,26}$

Based on the above findings, one could assume that the use of DPP-4 inh may increased amylase and lipase levels in patients who do not exhibit symptoms of acute pancreatitis. Thus, DPP-4 inh should be used with caution in patients at risk for pancreatitis and pancreatic cancer. Moreover, patients using DPP-4 inh, especially sitagliptin, should be evaluated carefully for pancreatitis risk factors.

Conflicts of interest: No conflict of interest was declared by the authors.

\section{REFERENCES}

1. Hopsu-Havu VK, Glenner GG. A new dipeptide napthylamidase hydrolyzing glycl-prolyl-beta-naphthylamide. Histochemie. 1966;7:197201.

2. Gautier JF, Choukem SP, Girard J. Physiology of incretins (GIP and GLP1) and abnormalities in type 2 diabetes. Diabetes Metab. 2008;34(Suppl 2):65-72.

3. International Diabetes Federation. Diabetes Atlas; (6th ed). 2013:32-34. Available from: https://www.idf.org/e-library/epidemiology-research/ diabetes-atlas/19-atlas-6th-edition.html

4. Inzucchi SE, McGuire DK. New drugs for the treatment of diabetes: part II: incretin-based therapy and beyond. Circulation. 2008;117:574-584.

5. Mentlein R, Gallwitz B, Schmidt WE. Dipeptidyl-peptidase IV hydrolyses gastric inhibitory polypeptide, glucagon-like peptide-1 (7-36) amide, peptide histidine mehtionine and is responsible for their degradation in human serum. Eur J Biochem. 1993;214:829-835.

6. Spranger J, Gundert-Remy U, Stammschulte T. GLP-1-based therapies: the dilemma of uncertainty. Gastroenterology. 2011;141:20-23.

7. Elashoff M, Matveyenko AV, Gier B, Elashoff R, Butler PC. Pancreatitis, pancreatic, and thyroid cancer with glucagon-like peptide-1-based therapies. Gastroenterology. 2011;141:150-156.

8. White WB, Cannon CP, Heller SR, Nissen SE, Bergenstal RM, Bakris GL, Perez AT, Fleck PR, Mehta CR, Kupfer S, Wilson C, Cushman WC, Zannad F; EXAMINE Investigators. Alogliptin after Acute Coronary Syndrome in Patients with Type 2 Diabetes. N Engl J Med. 2013;369:1327-1335.

9. Egan AG, Blind E, Dunder K, de Graeff PA, Hummer BT, Bourcier T, Rosebraugh C. Pancreatic safety of incretin-based drugs-FDA and EMA assessment. N Engl J Med. 2014;370:794-797.

10. Butler PC, Dry S, Elashoff R. GLP-1-based therapy for diabetes: what you do not know can hurt you. Diabetes Care. 2010;33:453-455.

11. Gier B, Matveyenko AV, Kirakossian D, Dawson D, Dry SM, Butler PC. Chronic GLP-1 receptor activation by exendin-4 induces expansion of pancreatic duct glands in rats and accelerates formation of dysplastic lesions and chronic pancreatitis in the Kras(G12D) mouse model. Diabetes. 2012;61:1250-1262.

12. Tatarkiewicz K, Smith PA, Sablan EJ, Polizzi CJ, Aumann DE, Villescaz C, Hargrove DM, Gedulin BR, Lu MG, Adams L, Whisenant T, Roy D, Parkes DG. Exenatide does not evoke pancreatitis and attenuates chemically induced pancreatitis in normal and diabetic rodents. Am J Physiol Endocrinol Metab. 2010;299:1076-1086.

13. Koehler JA, Baggio LL, Lamont BJ, Ali S, Drucker DJ. Glucagon-like peptide-1 receptor activation modulates pancreatitis-associated gene expression but does not modify the susceptibility to experimental pancreatitis in mice. Diabetes. 2009;58:2148-2161.

14. Gale EA. GLP-1-based therapies and the exocrine pancreas: more light, or just more heat? Diabetes. 2012;61:986-988.

15. Strobel O, Rosow DE, Rakhlin EY, Lauwers GY, Trainor AG, Alsina J, Fernández-Del Castillo C, Warshaw AL, Thayer SP. Pancreatic duct glands are distinct ductal compartments that react to chronic injury and mediate Shh-induced metaplasia. Gastroenterology. 2010;138:11661177.

16. Goggins M. GLP-1 receptor agonist effects on normal and neoplastic pancreata. Diabetes 2012;61:989-990.

17. Butler AE, Campbell-Thompson M, Gurlo T, Dawson DW, Atkinson M, Butler PC. Response to comments on: Butler et al. Marked expansion of exocrine and endocrine pancreas with incretin therapy in humans with increased exocrine pancreas dysplasia and the potential for glucagonproducing neuroendocrine tumors. Diabetes 2013;62:2595-2604. Diabetes. 2013;62:19-22.

18. Heine RJ, Fu H, Kendall DM, Moller DE. Comment on: Butler et al. Marked Expansion of Exocrine and Endocrine Pancreas With Incretin Therapy in Humans With Increased Exocrine Pancreas Dysplasia and the Potential for Glucagon-Producing Neuroendocrine Tumors. Diabetes. 2013;62:16-17.

19. Engel SS, Golm GT, Lauring B. Comment on: Butler et al. Marked expansion of exocrine and endocrine pancreas with incretin therapy in humans with increased exocrine pancreas dysplasia and the potential for glucagon-producing neuroendocrine tumors. Diabetes 2013;62:2595-2604. Diabetes. 2013;62:18.

20. Köroğlu Kale B, Songür $Y$, Ersoy IH, Köroğlu M, Akın M, Tamer MN. Sitagliptin and Acute Pancreatitis: Cases and Literature Review. Turkiye Klinikleri J Med Sci. 2012;32:859-864.

21. Li L, Shen J, Bala MM, Busse JW, Ebrahim S, Vandvik PO, Rios LP, Malaga G, Wong E, Sohani Z, Guyatt GH, Sun X. Incretin treatment and risk of pancreatitis in patients with type 2 diabetes mellitus: systematic review and meta-analysis of randomised and non-randomised studies. BMJ. 2014:348:2366.

22. Chou HC, Chen WW, Hsiao FY. Acute Pancreatitis in Patients with Type 2 Diabetes Mellitus Treated with Dipeptidyl Peptidase-4 Inhibitors: A Population-Based Nested Case-Control Study. Drug Saf. 2014;37:521528.

23. Yabe D, Seino Y. Use of the Japanese health insurance claims database to assess the risk of acute pancreatitis in patients with diabetes: comparison of DPP-4 inhibitors with other oral antidiabetic drugs. Diabetes Obes Metab. 2015;17:430-434.

24. Tokuyama H, Kawamura H, Fujimoto M, Kobayashi K, Nieda M, Okazawa T, Takemoto M, Shimada F. A low-grade increase of serum pancreatic exocrine enzyme levels by dipeptidyl peptidase- 4 inhibitor in patients with type 2 diabetes. Diabetes Res Clin Pract. 2013;100:66-69. 
25. Ferreira L, Teixeira-de-Lemos E, Pinto F, Parada B, Mega C, Vala H, Pinto R, Garrido P, Sereno J, Fernandes F, Santos P, Velada I, Melo A, Nunes S, Teixeira F, Reis F. Effects of Sitagliptin Treatment on Dysmetabolism, Inflammation, and Oxidative Stress in an Animal Model of Type 2 Diabetes (ZDF Rat). Mediators Inflamm. 2010;2010:592760.
26. Nauck MA, Meininger G, Sheng D, Terranella L, Stein PP; Sitagliptin Study 024 Group. Efficacy and safety of the dipeptidyl peptidase-4 inhibitor, sitagliptin, compared with the sulfonylurea, glipizide, in patients with type 2 diabetes inadequately controlled on metformin alone: a randomized, double-blind, non-inferiority trial. Diabetes Obes Metab. 2007;9:194-205. 